\title{
ЗАКОНОМЕРНОСТИ РАСПРЕДЕЛЕНИЯ ГЛИНИСТЫХ МИНЕРАЛОВ В ВЕНДСКИХ И КЕМБРИИСКИХ ОТЛОЖЕНИЯХ ВОСТОчноЙ ЭСТОНиИ
}

\begin{abstract}
Сведения о составе глинистой фракции вендских и кембрийских отложений Эстонию очень скудны и отрывочны. Опубликованные до сих пор работы затрагивают в основном только эксплуатируемую часть верхов толщи «синих глин» лонтоваской, отчасти пиритасксй свиты и, как правило, весьма слабо привязаны к стратиграфии разреза (Pralow, 1938; Дилакторский, 1953, 1956; Пальмре, 1960; Pейер, 1965a, 19656; Utsal. 1969). Данные о глинистых минералах других частей разреза приведены лишь в отдельных публикациях, посвященных рассмотрению частных вопросов геологии кембрийских и вендских отложений (Паасикиви, 1966; Менс, Пиррус, 1970; Mens, Pirrus, 1967).

В настоящей статье излагаются материалы систематического исследования качественного и количественного распределения глинистых минералов в семи разрезах восточной части Эстонии, где вендские, в меньшей степени и кембрийские терригенные отложения, представлены наиболее полно и большими мощностями (до $220 \mathrm{M}$ ). Представленный материал базируется на исследовании фракции $<0,001$ м.и из 317 проб. осадочных пород, по которым выполнено 275 термических, 155 рентгеноструктурных, 55 полных и 70 специальных химических анализов. Термические и химические исследования проводились в лабораториях Института геологии АН ЭССР, рентгеноструктурные - в минералогическом кабинете кафедры геологии ТГУ К. Утсалом.
\end{abstract}

\section{Состав и характеристика глинистых минералов разреза}

В результате проведенных исследований в вендских и кембрийских отложениях установлено присутствие трех групп минералов: каолинита, гидрослюд и хлоритсв. Минералы с разбухающей структурой типа монтмориллонит или вермикулит в виде самостсятельной минеральной фазы нигде не обнаружены. В ряде образцов установлены только следы $(5-10 \%)$ неупорядоченных смешанно-слойных минералов типа гидрослюда-монтмориллонит, однако из-за ничтожного содержания этих компонентов невозможно дать их более подробную характеристику. При количественных расчетах эти образования условно рассматриваются как наиболее деградированные разности гидрослюд, в состав которых они и включены.

Рентгенограммы глинистой фракции исследованных пород обладают весьма четкими рефлексами и характеризуются слабым фоном, что свидетельствует о сравнительно хорошей окристаллизованности глинистых минералов и об отсутствии в составе тонкой фракции значительных количеств рентгеноаморфных продуктов. Из неглинистых минералов в составе фракции $<0,001$ мм установлена спорадическая примесь кварца (до 5-7\%), реже обнаружены следы кальцита, доломита и сидерита. В красноцветных отложениях валдайской серии часто присутствует тонкодисперсный гематит $(5-25 \%)$, в охристых корах выветривания ляминари- 
товых и «синих» глин - гетит (до 20\%). При количественной характеристике состава глинистой фракции эти минералы не учтены. Общий минералогический состав фракции $<0,001$ мм отражается во взаимоотношениях породообразующих окислов, представленных в таблице.

Гид рослюды исследованного разреза в основном диоктаэдрического типа, характернзующиеся обычной для слюдистой решетки серией рефлексов, в частности рефлексом $(060)$ в 1,503-1,508 $\mathbf{A}$. Базальноз отраженне в $10 . \tilde{\mathbf{A}}$ имеет, как правило, вил четкого пика, иногда лишь слегка затененного в сторону малых углов отражения. Только изредка в таких образцах после обработки этиленгликолем наблюдается пояьление едва заметного дополнительного рефлекса в 11,5-12,0 $\AA$, позволяющего предполагать примесь смешанно-слойных образований с высокогидратизированными слоямн в пакете (эффект исчезает при нагревании). В одном случае после нагревания наблюдается появление слабого рефлекса в $14 \AA$, свидетельствующего о возможном присутствии неупорядоченных смешанно-слойных сростков типа монтмориллонит-хлорит. Однако эти единичные и незначительные по масштабу проявления смешанно-слойных фаз пе обнаруживают отчетливой приуроченности к какой-либо определенной части разреза, а весьма случайно разбросаны по нему. Это дает основание рассматривать их в качестве метастабильных промежуточных продуктов изменения основного гидрослюдистого компонента фракции $<0,001$ мм.

Судя по разнообразию относительных интенсивностей базальных рефлексов первых порядков, гидрослюдистый компонент рассматриваемых отложений представлен весьма разнообразными образованиями, имеющими значительные колебания не только в степени гидратации, но и в характере заселения октаэдрических позиций решетки различными трехвалентными катионами. Перерасчет химических анализов позволяет охарактеризовать суммарный кристаллохимический состав гидрослюдистого компонента отдельных стратиграфических комплексов в виде следующих формул:

Пи ритаск ая свита:

1) Скв. Яама, гл. $149,6 \mathrm{M},\left[\mathrm{K}_{0,6}\left(\mathrm{H}_{3} \mathrm{O}\right)_{0,3} \mathrm{Na}<0,1\right]_{1}\left(\mathrm{Al}_{1,6} \mathrm{Fe}_{0,2}^{3+} \mathrm{Mg}_{0,2}\right)_{2}\left(\mathrm{Si}_{3,8} \mathrm{Al}_{0,2}\right)_{4}$ $\mathrm{O}_{10}\left[\mathrm{O}_{0,6}(\mathrm{OH})_{1,4}\right]_{2}$.

Лонтоваская свита:

2) Скв. Кунда, гл. $48,3 \mathrm{M},\left[\mathrm{K}_{0,5}\left(\mathrm{H}_{3} \mathrm{O}\right)_{0,4} \mathrm{Na}<0,1\right]_{1}\left(\mathrm{Al}_{1,4} \mathrm{Fe}_{0,2}^{3+} \mathrm{Fe}_{0,2}^{2+} \mathrm{Mg}_{0,2}\right)_{2}\left(\mathrm{Si}_{3,7} \mathrm{Al}_{0,3}\right)_{4}$ $\mathrm{O}_{10}\left[\mathrm{O}_{0,3}(\mathrm{OH})_{1,7}\right]_{2}$.

3) Скв. Петсери, гл. 490,1 м, $\left[\mathrm{K}_{0,6}\left(\mathrm{H}_{3} \mathrm{O}\right)_{0,4} \mathrm{Na}<0,1\right]_{1}\left(\mathrm{Al}_{1,7} \mathrm{Fe}_{0,2}^{3+} \mathrm{Fe}_{<-11}^{2+} \mathrm{Mgg}_{0,1}\right)_{2}\left(\mathrm{Si}_{3,8} \mathrm{Al}_{0,2}\right)_{4}$ $\mathrm{O}_{10}\left[\mathrm{O}_{0,6}(\mathrm{OH})_{1,4}\right]_{2}$.

Регрессивная часть валдайской серин:

4) Скв. Яама, гл. $227,6 \mu$, $\left[\mathrm{K}_{0,7}\left(\mathrm{H}_{3} \mathrm{O}\right)_{0,3} \mathrm{Na}<0,1\right]_{1}\left(\mathrm{Al}_{1,3} \mathrm{Fe}_{0,3}^{3+} \mathrm{Fe}_{<0,2}^{2+} \mathrm{Mg}_{0,2}\right)_{2}\left(\mathrm{Si}_{3,1} \mathrm{Al}_{0,2}\right)_{4}$ $\left[\mathrm{O}_{9,7}(\mathrm{OH})_{0,3}\right]_{10}(\mathrm{OH})_{2}$.

Котлннская свита:

5) Скв. Яама, гл. $245,1 \mu,\left[\mathrm{K}_{0,7}\left(\mathrm{H}_{3} \mathrm{O}\right)_{0,3} \mathrm{Na}_{<0,1}\right]_{1}\left(\mathrm{Al}_{1,7} \mathrm{Fe}_{0,2}^{3+} \mathrm{Mg}_{0,1}\right)_{2}\left(\mathrm{Si}_{3,9} \mathrm{Al}_{0,1}\right)_{4}$ $\mathrm{O}_{10}\left[\mathrm{O}_{0,8}(\mathrm{OH})_{1,2}\right]_{2}$.

6) Скв. Синимяэ, гл. $158,2 \mu,\left[\mathrm{K}_{0,6}\left(\mathrm{H}_{3} \mathrm{O}\right)_{0,4} \mathrm{Na}<0,1\right]_{1}\left(\mathrm{Al}_{1,2} \mathrm{Fe}_{0,2}^{3+} \mathrm{Fe}_{0,3}^{2+} \mathrm{Mg}_{0,3}\right)_{2}\left(\mathrm{Si}_{3,5} \mathrm{Al}_{0,5}\right)_{4}$ $\left[\mathrm{O}_{9,8}(\mathrm{OH})_{0,2}\right]_{10}(\mathrm{OH})_{2}$.

Гдовская свита:

7) Скв. Яама, гл. $292,7 \mu,\left[\mathrm{K}_{0,7}\left(\mathrm{H}_{3} \mathrm{O}\right)_{0,3} \mathrm{Na}_{<0,1}\right]_{1}\left(\mathrm{Al}_{1,4} \mathrm{Fe}_{0,3}^{3+} \mathrm{Fe}_{0,1}^{2+} \mathrm{Mg}_{0,2}\right)_{2}\left(\mathrm{Si}_{3,4} \mathrm{Al}_{0,6}\right)_{4}$ $\mathrm{O}_{10}\left[\mathrm{O}_{0,1}(\mathrm{OH})_{1,9}\right]_{2}$.

8) Скв. Ухтна, гл. $274,1 M\left[\mathrm{~K}_{0,6}\left(\mathrm{H}_{3} \mathrm{O}\right)_{0,4}\right]_{1}\left(\mathrm{Al}_{1,3} \mathrm{Fe}_{0,3}^{3+} \mathrm{Fe}_{0,1}^{2+} \mathrm{Mg}_{0,3}\right)_{2}\left(\mathrm{Si}_{3,4} \mathrm{Al}_{0,6}\right)_{4} \mathrm{O}_{10}(\mathrm{OH})_{2}$.

Эти данные показывают, что из гидрослюдистого компонента в целом выщелочено $30-45 \%$ калия, что соответствует гидрослюдам (в узком смысле) по номенклатуре И. Гинзбурга (1953). Кристаллохимические формулы указывают и на заметную 


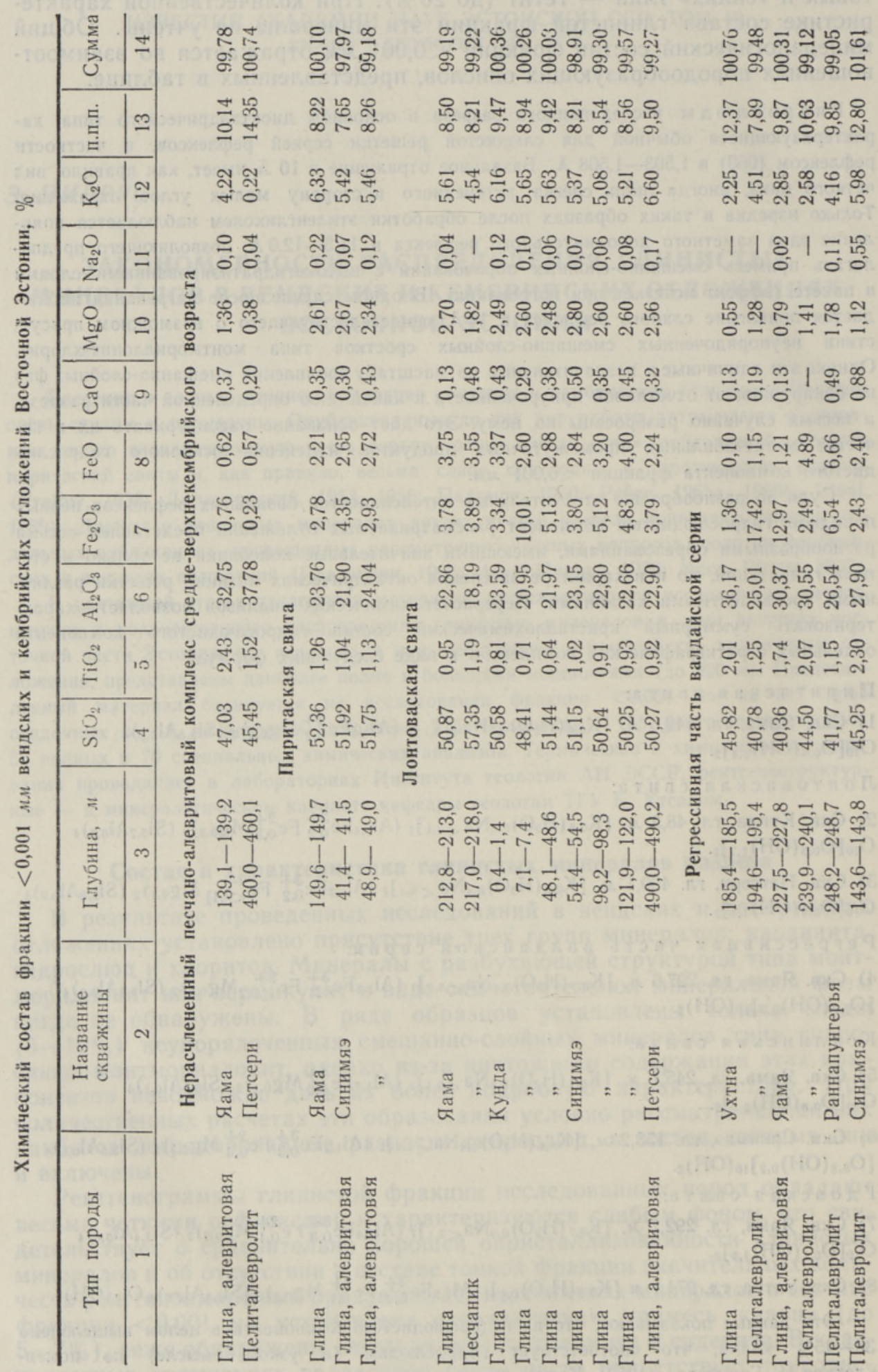


= \&

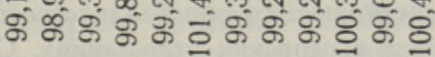

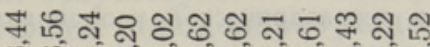

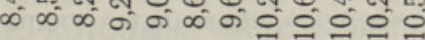

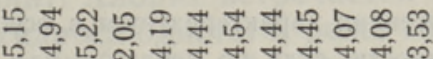

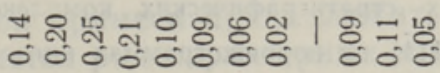

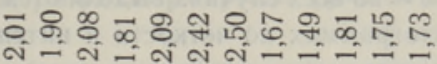

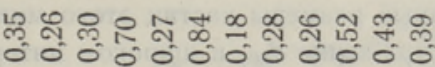
œ

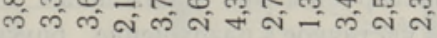

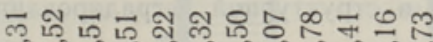

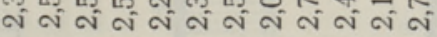

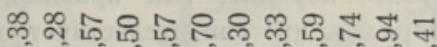

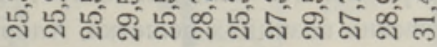
엉 음

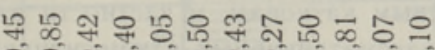

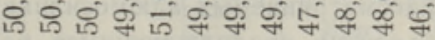

ㅇ. $\alpha$ ก

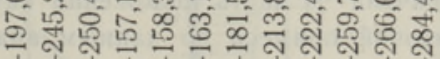

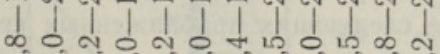

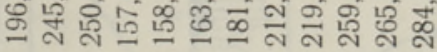

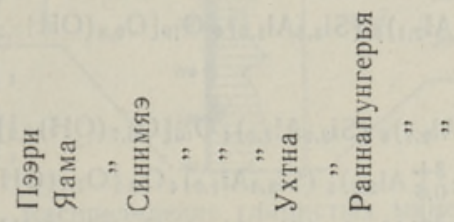

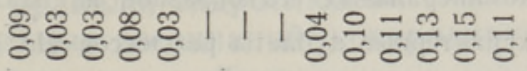

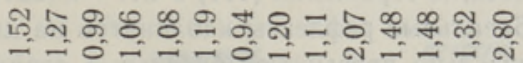

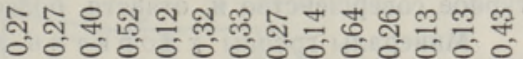

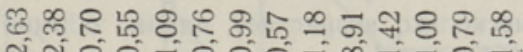

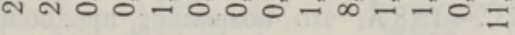

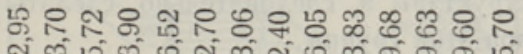

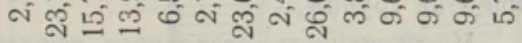

สิ

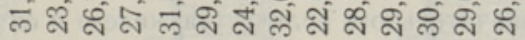

ํㅗㄴ

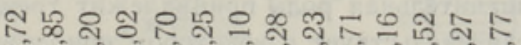

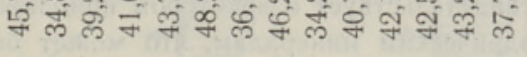

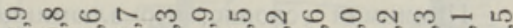

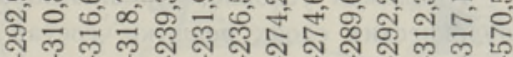

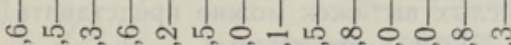
๙ิ่

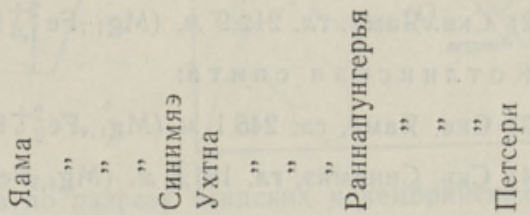

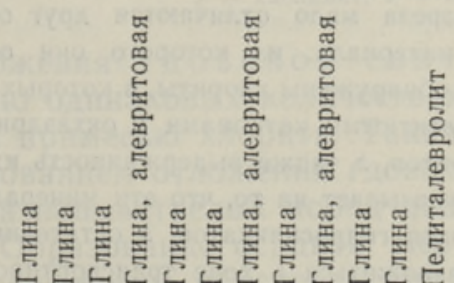

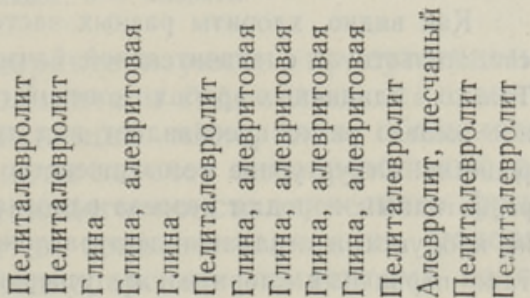


роль железа и магния в октаэдрическом слюе решетки, что, очевидно, говорит о формировании части гидрослюд за счет продуктов разложения железистых слюд, широко распространенных в гнейсовой формации подсгилающего кристаллического фундамента. Особенно заметна роль трехвалентного железа в гдовских отложениях. Следует также отметить незначительную роль алюминия в тетраэдрической координации, в частности, в кембрийских отложениях, что лишь частично объясняется гидратированностью первичной слюдистой решетки.

К а олини т в рассматриваемых отложениях характеризуется в основном средней и даже хорошей степенью окристаллизованности, судя по дебаэграммам наиболее мономинеральных его образцов из различных стратиграфических комплексов. Правда, характерные дублеты рефлексов $(1 \overline{1})$ и $(1 \overline{1} \overline{1})$ на порошкограммах нигде не наблюда.

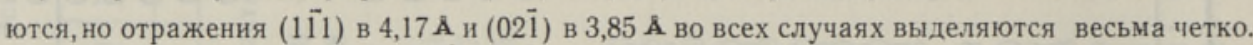
Базальные рефлексы каолинитов на дифрактограммах по четкости и интенсивности значитєльно превышают базальные отражения гидрослюд, что также указывает на структурное совершенство и, отчасти, более крупные размеры частиц этого минерала.

Мннералы группы хлори тов дают отражение $d_{001}$ в широком интервале, в большинстве образцов от 12,0 до $14,6 \AA$. После нагревания до $500^{\circ} \mathrm{C}$ четкость этого рефлекса несколько возрастает, однако обычно он фиксируется при заниженных значениях - в 13,2-13,8 А, что позволяет предположить частичное разрушение бруситовых слоев структуры и, следовательно, сделать вывод о структурной деградированности мннераяов этой группы.

Интенсивность базального рефлекса первого порядка, как правило, значительно уступает интенсивности рефлекса второго порядка, что свидетельствует о присутствни значнтельного количества железа в октаэдрических позициях решетки. Хлориты довольно легко растворяются в $\mathrm{HCl}$ : после двухчасовой выдержки в горячей $10 \%$-ной $\mathrm{HCl}$ рефлексы их на дифрактограммах не обнаруживаются. Судя по составу катионов в солянокислых вытяжках, хлориты разреза имеют весьма сложный состав и в структуре их знгчительная роль принадлежит трехвалентным катионам, в частности алюминию. Эло свидетельствует о некотором приближении рассматриваемых алюмосиликатов к диоктаэдрическим минералам, что может быть объяснено продолжающимся разложением и окислением их первоначальной формы в ходе осадконакопления.

Принимая условно, что алюминием охвачена $1 / 4$ часть положений катионов в тетраэдрических слоях решетки, состав хлоритовой примеси по данным анализа солянокислых вытяжек можно представить в виде следующих приближенных кристаллохимических формул:

Лонтов аская свита:

1) Скв. Кунда, гл. 1,0 м, $\left(\mathrm{Mg}_{1,5} \mathrm{Fe}_{1,0}^{2+} \mathrm{Fe}_{0,9}^{3+} \mathrm{Al}_{2,6}\right)_{6}\left(\mathrm{Si}_{3,0} \mathrm{Al}_{1,0}\right)_{4} \mathrm{O}_{10}\left[\mathrm{O}_{1,3}(\mathrm{OH})_{6,7}\right]_{8}$.

2) Скв. Яама, гл. 212,9 м, $\left(\mathrm{Mg}_{1,7} \mathrm{Fe}_{1,6}^{2+} \mathrm{Fe}_{0,5}^{3+} \mathrm{Al}_{2,1}\right)_{6}\left(\mathrm{Si}_{3,0} \mathrm{Al}_{1,0}\right)_{4} \mathrm{O}_{10}\left[\mathrm{O}_{0,8}(\mathrm{OH})_{7,2}\right]_{8}$.

Котлинская свита:

3) Скв. Яама, гл. $245,1 M\left(\mathrm{Mg}_{1,4} \mathrm{Fe}_{2,2}^{2+} \mathrm{Fe}_{0,3}^{3+} \mathrm{Al}_{2,1}\right)_{6}\left(\mathrm{Si}_{3,0} \mathrm{Al}_{1,0}\right)_{4} \mathrm{O}_{10}\left[\mathrm{O}_{0,7}(\mathrm{OH})_{7,3}\right]_{8}$.

4) Скв. Синимяэ, гл. $181,5 \mathrm{M},\left(\mathrm{Mg}_{1,3} \mathrm{Fe}_{1,5}^{2+} \mathrm{Fe}_{0,6}^{3+} \mathrm{Al}_{2,6}\right)_{6}\left(\mathrm{Si}_{3,0} \mathrm{Al}_{1,0}\right)_{4} \mathrm{O}_{1}\left[\mathrm{O}_{1,1}(\mathrm{OH})_{6,9}\right]_{8}$.

5) Скв. Синимяэ, гл. $158,2 \mathrm{M},\left(\mathrm{Mg}_{1,5} \mathrm{Fe}_{1,2}^{2+} \mathrm{Fe}_{1,0}^{3+} \mathrm{Al}_{2,3}\right)_{6}\left(\mathrm{Si}_{3,0} \mathrm{Al}_{1,0}\right)_{4} \mathrm{O}_{1 \mathrm{c}}\left[\mathrm{O}_{1,2}(\mathrm{OH})_{6,8}\right]_{8}$.

Как видно, хлориты разных частей разреза мало отличаются друг от друга, чтэ свидетельствует о значительной близости материала, из которого они образовались. Только в единичных пробах гдовской свиты обнаружены хлориты, в которых двухвалентное железо резко преобладает над трехвалентными катионами в октаэдрическом слое решетки. Структурное несовершенство хлоритов, а также выдержанность их состава по разногиным породам разреза однозначно указывает на то, что эти минералы являются не продуктами аградации полуразложившихся гидросиликатов, а остаточными продуктами первичных хлоритов, на успевших разложиться в ходе транспортировки и седиментации глинистой взвеси. 


\section{Распределение глинистых минералов по вертикальному разрезу}

Несмотря на сравнительно маложомпонентный состав глинистых минералов, в разрезе вендско-кембрийских отложений Восточной Эстонии практически отсутствуют мономинеральные разности фракции $<0,001$ мм. Главенствующее породообразующее значение по всему разрезу имеют гидрослюды, которым часто в весьма различных количествах сопутствуєт каолинит. Хлорит встречается в качестве примеси обычно в тонких фракциях гидрослюдистого, реже гидрослюдисто-каолинитового состава. В богатых каолинитом образцах из различных частей разреза роль второстепенной примеси принадлежит, как правило, гидрослюдам.

Отмечается ряд характерных минеральных ассоциаций, контролируемых стратиграфией разреза (рис. 1).

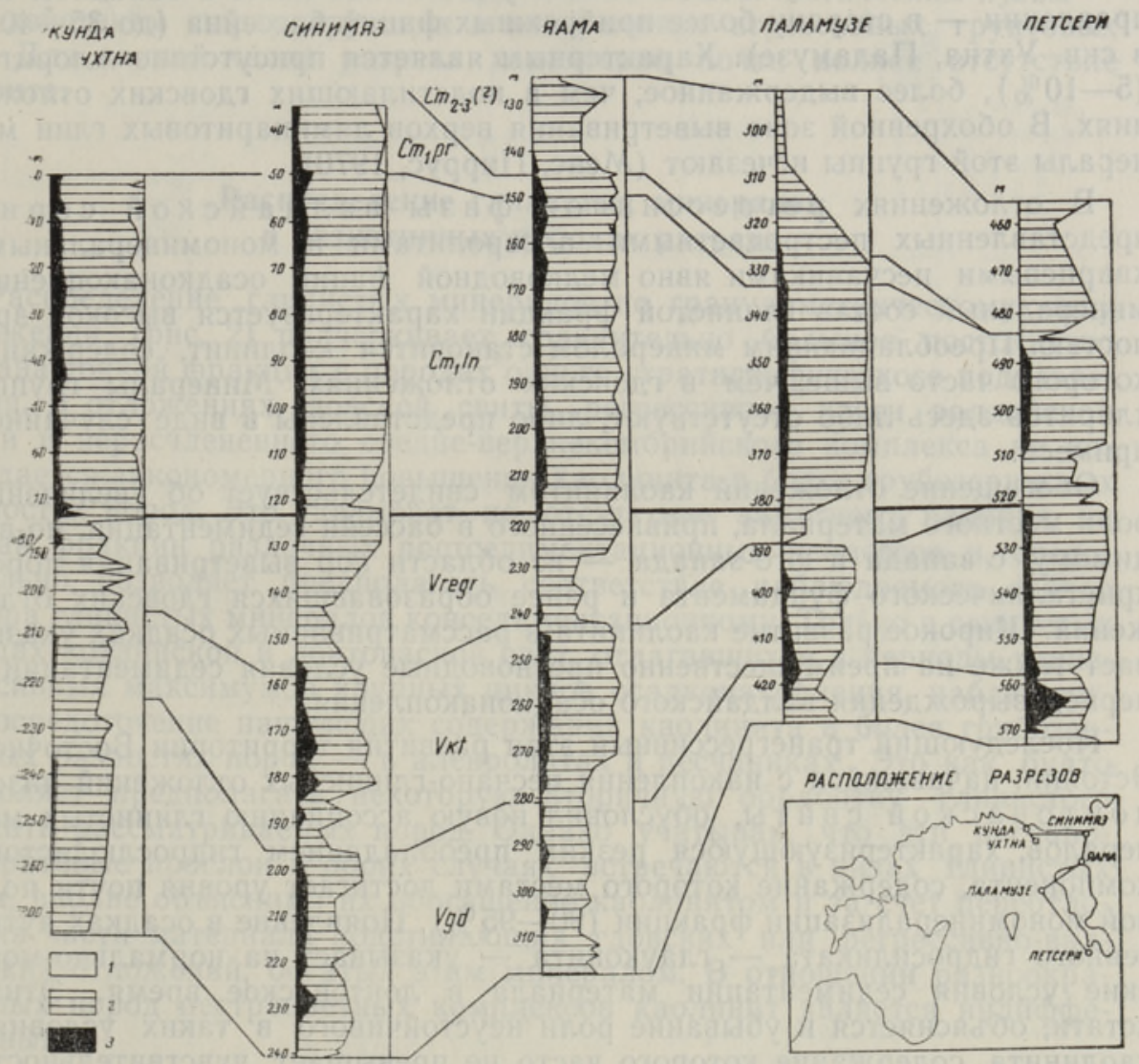

Рис. 1. Распределение глинистых минералов по разрезу вендских и кембрийских отложений Восточной Эстонин:

1 - каолинит; 2 - гидрослюды; 3 - хлориты.

Отложения гдовской свиты характеризуются присутствием в примерно одинаковых количествах каолинита и гидрослюд, с незначи . тельной примесью хлорита. Такая ассоциация минералов объясняется формированием отложений гдовской свиты за счет одновременного размыва разновыветрелых пород подстилающего кристаллического фундамента. Образование осадков местами в сильноокисляющих условиях (красноцветность, обусловленная тонкодисперсным гематитом) не спо- 
собствовало сохранению в них хлоритов, чем объясняется весьма спорадическое распространение этих минералов и, в частности, наличие нх только в сероцветных разностях пород. Однако отдельные случаи повышенной концентрации минералов этой группы (до $50 \%$ в скв. Петсери): все же указывают на близость первоисточника этих минералов - кристаллических пород фундамента.

Отложения котлинской свиты характеризуются несколько иным соотношением компонентов, что свидетельствует о существенной перестройке ко времени максимума валдайской трансгрессии схемы питания бассейна глинистым материалом. Тонкая взвесь, привнесенная в районы Восточной Эстонии, очевидно, с довольно удаленных областей размыва, состояла в основном из гидрослюдистых минералов. Каолинитовый компонент в составе глинистой фракции явно подавлен $(15-25 \%)$ и обнаруживает слабую тенденцию к увеличению лишь в западном направлении - в сторону более прибрежных фаций бассейна (до 35-40\%. в скв. Ухтна, Паламузе). Характерным является присутствие хлоритов. (5-10\%), более выдержанное, чем в подстилающих гдовских отложениях. В обохренной зоне выветривания верхов ляминаритовых глин минералы этой группы исчезают (Менс, Пиррус, 1970).

В отложениях регрессивной фазы валдай ской сери и, представленных пестроцветными алевролитами и мономинеральными кварцевыми песчаниками явно мелководной фации осадконакопления, минеральный состав глинистой фракции характеризуется высокой зрелостью. Преобладающим минералом становится каолинит, содержание которого часто выше, чем в гдовских отложениях. Минералы группы хлоритов здесь либо отсутствуют, либо представлены в виде случайной примеси.

Обогащение отложений каолинитом свидетельствует об увеличении роли местного материала, привнесенного в бассейн седиментации, по-видимому, с запада и юго-запада - из области кор выветривания пород кристаллического фундамента и ранее образовавшихся гдовских отложений. Широкое развитие каолинита в рассматриваемых осадках указывает также на преимущественно пресноводные условия седиментации в период вырождения валдайского осадконакопления.

Последующий трансгрессивный этап развития территории Восточной Эстонии, начавшийся с накопления песчано-глинистых отложений низов. лон тов а ской свиты, обусловил новую ассоциацию глинистых минералов, характеризующуюся резкнм преобладанием гидрослюдистого компонента, содержание которого местами достигает уровня почти полной мономинерализации фракции $(90-95 \%)$. Появление в осадках аутигенного гидросиликата - глауконита - указывает на нормально-морские условия седиментации материала в лонтоваское время. Этим, кстати, объясняется и убывание роли неустойчивого в таких условиях каолинита, содержание которого часто не превышает чувствительности дифрактометрического анализа $(5 \%)$. Хлоритовая примесь в лонтоваских отложениях встречается почти повсеместно.

Асссциация минералов в вышележащих отложениях люкатиской пачки п и рит а с кой свиты, образовавшихся в более мелководных условиях на базе переотложения глинистого материала верхов лонтоваской свиты, практически ничем не отличается от ассоциации минералов в лонтоваских глинах. Можно указать лишь на продолжающееся здесь убывание каолинита, о чем свидетельствуют случаи полного отсутствия этого минерала.

Нерасчлененный комплекс алевритово-песчаных отложений предпо- 
лагаемого с редн е-позднекемб р й ского воз р а с т а, ${ }^{*}$ залегающий на размытой или выветрелой поверхности перерыва на лонтоваских или пиритаских отложениях к югу от линии Виру-Роэла-Яама, характеризуется очень изменчивым составом глинистых минералов. Встречаются как почти мономинеральные гидрослюдистые или каолинитовые разности фракции $<0,001$ мм, так и разности с различной количественной комбинацией этих минералов. Такие колебания состава одинаково наблюдаются в маломощных глинистых прослоях и в рассеянном глинистом цементе алевролитов, при этом не выявлено каких-либо четких закономерностей ни в вертикальном, ни в горизонтальном распределении отдельных компонентов. Появление значительного количества каолинита можно объяснить поступлением этого минерала с каолинитовой. коры выветривания «синих глин» лонтоваской свиты (Паасикиви, 1966), но не исключено его частичное образование и катагенетическим путем -. под действием циркулирующих в алевролитах агрессивных грунтовых вод. Для данной части разреза характерно почти полное отсутствие хлорита.

\section{Распределение глинистых минералов в разнотипных породах разреза}

Распределение глинистых минералов по гранулометрическому типу стложений (рис. 2) подчеркивает сравнительно большое постоянство состава тонкой фракции в породах одного стратиграфического подразделения. В отложениях гдовской свиты, регрессивной части валдайской серии и нерасчлененного средне-верхнекембрийского комплекса не наблюдается закономерного повышения каолинита в более грубозернистых разностях пород. Это указывает на отсутствие заметного влияния на. состав фракции различных постседиментационных процессов и, следовательно, позволяет предполагать соответствие наблюдаемого сейчас набора глинистых минералов конседиментационному. Только в глинистых толщах котлинской и лонтоваской свит, отлагавшихся в периоды трансгрєссивных максимумов крупных циклов осадконакопления, наблюдается сосредоточение наивысших содержаний каолинита в более грубозернистых разностях пород - в алевролитах и песчаниках. Это как будто позволяет предполагать некоторую вторичную обработку глинистого. цемента рассматриваемых пород. Однако учитывая, что эти песчаноалевритовые прослои в обоих случаях встречаются в низах глинистых. толщ, вполне объяснимо их обогащение каолинитом и за счет переотложения части материала подстилающих гдовских или регрессивно-валдайских отложений, богатых этим минералом. В отношении разноокрашенных пород пестроцветных комплексов каолинит является индифферентным.

Содержание хлоритов в разнотипных породах также характеризуется большим постоянством. Отмечается только связь единичных аномально: высоких содержаний их с песчаными разностями пород (гдовские и лонтоваские свиты, отложения регрессивной части валдайской серии). Очень слабо выражена склонность сосредоточения более высоких фоно. вых концентраций этих минералов либо в наиболее тонкодисперсных: глинах (лонтоваская и пиритаская свиты), либо, наоборот, в сильно-

* В настоящей статье не рассматриваются особенности состава глинистых минералов тискреской и верхней части пиритаской свит (какумягиской пачки), имеющих: ограниченное распространение в приглинтовой полосе Восточной Эстонии и более хахарактерных для западных районов республики. 

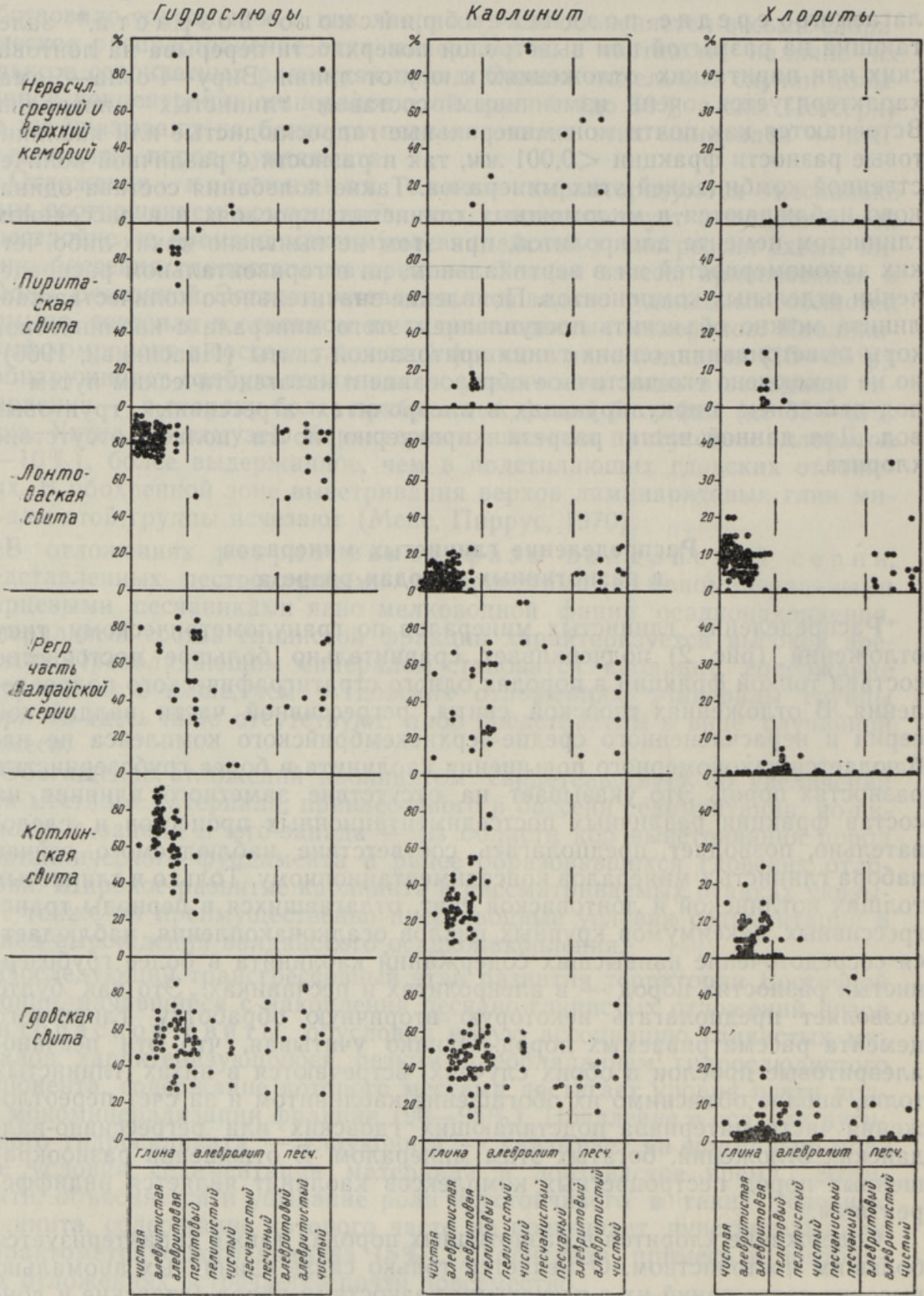

Рис. 2. Распределение содержаний глинистых минералов в породах различного гранулометрического состава.

Точками обозначены единичные определения.

алевритистых глинах (котлинская свита). В пестроцветных отложениях валдайской серии хлориты, как правило, встречаются только в разностях, лишенных свободных окисей-гидроокисей железа. В глинах лонтоваской свиты присутствие хлоритов не зависит от окраски породы: они 
присутствуют в примерно одинаковых количествах как в зеленоватосерых, так и в фиолетово-пестроокрашенных и даже в интенсивно-краснобурых разностях глин.

\section{Особенности гидрослюд в разновозрастных отложениях разреза}

Для более подробной характеристики главенствующего в рассматриваемом разрезе гидрослюдистого компонента изучались соотношения интенсивностей базальных рефлексов первых порядков этой группы минералов (рис. 3). Несмотря на то, что отношение $I_{001}: I_{002}$ колеблется в широком интервале, оно, если сохранять условия рентгеновской съемки, все же обнаруживает в виде статистической закономерности тенденцию изменяться при переходе с одного стратиграфического подразделения на другое. В то время как в отложениях гдовской свиты и регрессивной частіi валдайской серии гидрослюдистый компонент характеризуется значительным разбросом $I_{001}: I_{002}$, свидетельствующим о колебании состава гидрослюд в широких пределах, в глинистых отложениях трансгрессивных максимумов осадконакопления числовые данные этой величины несколько уравновешиваются и концентрируются вокруг определенных максимумов. При этом выявляется заметное различие между глинами котлинской и лонтоваской свит: у первых отношения $I_{001}: I_{002}$ чаще попадают в интервал $2,00-3,50$, у вторых - в $3,00-5,00$. Такое несов-

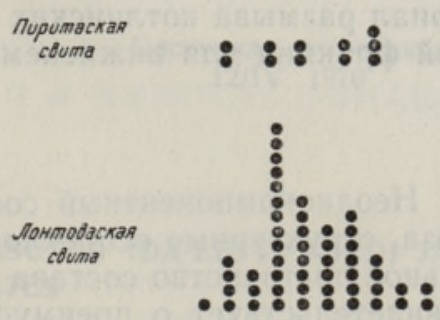

Perpeccudmas yacms Basgavickou cepui
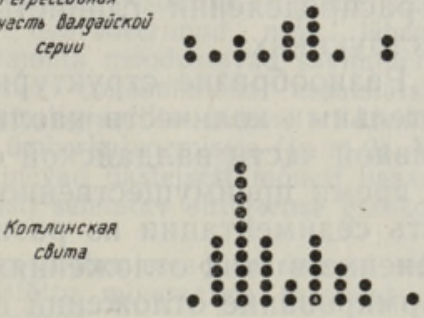

падение максимумов распределения как будто позволяет предполагать, что в гидрослюдистом компоненте нормально-морских отложений лонтоваской свиты замещение части алюминия в октаэдрических позициях железом имеет более широкое распространение, чем в ляминаритовых глинах. Однако расчет кристаллохимических формул это не подтверждает: из-за минимального замещения кремния алюминием в тетраэдрических позициях решетки основное количество $\mathrm{Al}$ входит в гидрослюдах лонтоваской свиты именно в октаэдрический слой, охватывая здесь $70-80 \%$ всех положений катионов (в котлинско-гдовских гидрослюдах это число обычно $60-70 \%$ ). В то же время пересчет данных химического анализа на гидрослюдистую -снову все же показывает сравнительную обогащенность гидрослюд лонтоваской свиты трехвалентным железом; в них отношение содержаний $\mathrm{Fe}_{2} \mathrm{O}_{3}$ и $\mathrm{Al}_{2} \mathrm{O}_{3}$ обычно находится в пределах от $1: 4,5$ до $1: 6,8$, в то время как в котлинских оно чаще всего менее $1: 6,0$. Такое кажущееся противорєчие объясняется, по всей вероятности, искажением интенсив- 
ностей дифракционных максимумов слюдистой решетки вследствие содержания в тонких фракциях кембрийских глин небольших количесть аутигенных сильножелезистых гидрослюд типа глауконит. На возможность присутствия в тонкой фракции «синих глин» гидрослюд разных генераций указывали ранее Н. Дилакторский (1956) и А. Рейер (1965a).

Этими особенностями в характере гидрослюд подчеркивается весьма существенное различие между рассмотренными основными глинистыми толщами венда и кембрия, что наряду с убыванием каолинитовой примеси вверх по разрезу указывает на заметное преобразование исходного глинистого материала в цикле нижнекембрийского осадконакопления: ведь нет сомнения, что на широких площадях Русской платформы именно материал размыва котлинских глин играл основную роль источника глинистой фракции для нижнекембрийских отложений.

\section{Выводы}

1. Неоднокомпонентный состав глинистой фракции исследованного разреза, структурные особенности хлоритов и гидрослюд, а также относительное постоянство состава минералов в разнотипных породах - все это свидетельствует о преимущественно аллотигенном происхождении глинистых минералов разреза и о значительной инертности их по отношению к различным постседиментационным процессам. Это позволяет без существенных поправок использовать спектр глинистой составляющей разнотипных пород для выявления закономерностей пространственного распределения глинистых минералов при палеогеографических реконструкциях.

2. Разнообразие структурной характеристики гидрослюд и наличие значительных количеств каолинита в отложениях гдовской свиты и регрессивной части валдайской серии свидетельствует о питании бассейна в это время преимущественно местным материалом, привнесенным в область седиментации из разновыветрелых пород прилегающей суши. Сохранение в этих отложениях больших количеств каолинита указывает на формирование отложений в условиях, близких к пресноводным.

3. Гидрослюдистый компонент отложений периодов максимальных трансгрессий имеет более уравновешенный характер и несколько изменяется при переходе от валдайских отложений к нормально-морским образованиям нижнего кембрия, что, по-видимому, объясняется некоторыми перестройками в его составе, происходящими в результате изменения гидрохимического режима как в воде бассейна, так и в иловом пространстве осадка.

4. Зависимость состава глинистых минералов в первую очередь от условий питания бассейна кластическим материалом обусловливает разделение весьма малокомпонентного сообщества глинистых минералов. на ряд количественных ассоциаций, хорошо контролируемых стратиграфией разреза.

\section{ЛИ ТЕРАТ У РА}

Д нлакторский Н. Л. 1953. К вопросу о термических свойствах глин Эстонской ССР. В сб.: Вопросы петрографии и минералогии, ІІ, М.

Д ил акторский Н. Л. 1956. Физико-химические свойства тонких фракций некоторых глин Эстонской ССР. Изв. АН ЭССР, Сер. техн. и физ.-матем. н., V, № 1.

Ги н з бург И. И. 1953. Стадийное выветривание слюд и хлоритов. В сб.: Вопросье петрографии и минералогии, II, М.

Менс К., Пир у с Э. 1970. Древняя кора выветривания ляминаритовых глин на северо-западе Русской платформы. II. Химико-минералогические изменення и условия образования. Изв. АН ЭССР, Хим. Геол., VIII, № 1. 
П а а с и к и в и Л. Б. 1966. Геологическое строение и история развития Ханья-Локновского и Мынистского поднятий. Вопр. разведочной геофизики, вып. 5.

П альм р е X. Г. 1960. Глины. Геология СССР, XXVIII, Эстонская ССР, М.

$\mathrm{P} \in$ й е p A. X. 1965a. Минералогические особенности кембрийских глин Эстонской ССР. Тр. Таллинск. политехн. ин-та, Сер. А, № 221.

$\mathrm{P}$ ей е р А. Х. 1965б. Рентгенографическое исследование кембрийских глин ЭССР. Тр. Таллинск. политехн. ин-та, Сер. А, № 221.

Mens K., P irrus E. 1967. Vendi kompleksi ja kambriumi ladestu mineraloogilistest iseärasustest Eestis. VIII Eesti Loodusuurijate Päeva ettekannete teesid, Tartu.

Pralow W. 1938. Mikroskopische, röntgenographische und chemische Untersuchung einiger Proben des estländischen Blatien Tons. Chemie der Erde, 11, 4.

Ut s a 1 K. 1969. Eestis leiduvatest savimineraalidest. Loodusuurijate Seltsi aastaraamat, 60, Tallinn,

Ннститут геологии

Академии наук Эстонской ССР

Поступила в редакцию

12/IV 1970

\section{E. PIRRUS}

\section{SAVIMINERAALIDE ESINEMISSEADUSPÄRASUSED IDA-EESTI VENDI JA KAMBRIUMI SETETES}

Ida-Eesti vendi ja kambriumi setete savimineraalide koosluses, mida uuriti kompleksse metoodikaga 7 puurprofiili alusel, esineb kolm rühma mineraale, nimelt kaoliniiti, hüdrovilke ja kloriite, üksikutes proovides jälgedena ka segakihtstruktuuriga moodustisi. Nende mineraalide esinemine mitmesuguses vahekorras määrabki fraktsiooni $<0,001 \mathrm{~mm}$ keemilise koostise (tab.). Hüdrovilkne komponent on keskmise hüdratatsiooniastmega ning sisaldab oktaeedrilises kihis Al kõrval ka $20-30 \%$ Fe ja Mg. Kaoliniit on suhteliselt hea kristallisatsiooniastmega. Kloriidid on struktuurilt degradeerunud ning lähenevad dioktaeedrilisele tüübile. Oma väikesearvulisusele vaatamata moodustavad savimineraalid vertikaalläbilōikes mitmeid stratigraafiliselt piiritletud iseloomulikke assotsiatsioone (joon. 1). Tähtsusetud muutused nende koosluses ühe stratigraafilise taseme eri kivimitüüpides viitavad nende väga nōrgale postsedimentaarsele ümberkujunemisele (joon. 2). Vendi kotlini ja kambriumi lontova kihistute hüdrovilgud erinevad üksteisest mōneti basaalreflekside intensiivsuse poolest (joon. 3). See on nähtąvasti seletatav autigeense glaukoniidi ilmumisega kambriumi setetesse.

Savimineraalide struktuurilised iseärasused, eelkõige jaotumisseaduspärasused setetes, viitavad selgelt nende allotigeensele tekkeviisile, mistōttu mineraalide assotsiatsioonid võimaldavad oluliselt täpsustada kivimite kuhjumistingimusi.

\section{E. PIRRUS}

\section{THE DISTRIBUTION OF CLAY MINERALS OF VENDIAN AND CAMBRIAN DEPOSITS IN EAST ESTONIA}

Seven core sections of Vendian and Cambrian deposits in East Estonia were complexly analyzed for clay mineral associations. Three groups of clay minerals are present kaolinite, hydromica and chlorite. In single samples small quantities of mixed-layer minerals have been established. The chemical composition of the fraction with a diameter $<1 \mu$ depends upon the relative amounts of different mineral groups (see Table). The hydromicaceous component has a medium degree of hydratation and contains up to $20-30 \% \mathrm{Fe}$ and $\mathrm{Mg}$ in the octahedral layer together with Al. Kaolinite shows a relatively high degree of crystallization. The structure of chlorite is degraded, approaching the dioctahedral type. The clay minerals compose stratigraphically well characterized associations in the vertical sequence of Vendian and Cambrian (Fig. 1). Minor changes of the composition of clay mineral associations, noted in different sedimentary rocks of a certain stratigraphical unit, indicate a very weak post-sedimentary transformation of the deposits (Fig. 2). Comparing the hydromicas of the Kotlian Formation of Vendian with the hydromicas of Lontova Formation of Cambrian we could note some differences in the initensity of basal reflexes which are apparently explained by the presence of glauconite in the Cambrian deposits (Fig. 3).

The structural pecularities of clay minerals, first of all their regularity in despersion, distinctly point to an allothigenic genesis. According to this, we can use the mineral associations for determining depositional conditions. 